\title{
Theories about the financial crises
}

Irina-Raluca Busuioc-Witowschi, “Alexandru Ioan Cuza” University of Iaşi, , Romania

\begin{abstract}
The financial crises are generally associated with banking crises due to the role they play in their production, transmission and settlement. This paper presents a number of different approaches taken from the specialized literature on the causes that led to the outbreak of the financial crises.
\end{abstract}

\section{Keywords}

Financial crisis, banking crisis, monetarism, risk, uncertainty, informational asymmetry

JEL Code : G01, E50

\section{Introduction}

The financial crises represent a major concern for the economists because they are phenomena which raise questions regarding their future evolution, the impact on the world economy as a whole and on each of its sectors. In a globalized economy the financial crisis cannot be isolated to one country alone or to one geographical area as the rebound requires a common effort. To avoid the emergence of future financial crises, we need to identify the factors which trigger them.

In the study of financial crisis, different models have been developed if one takes into consideration that the mechanisms which cause the crises are not fully known and their consequences are manifold. Thus, in this thesis, I did a review of the specialized literature, presenting different approaches to the financial crises.

The banking system has a crucial role in economy because it allows the mobilization of the surplus funds to finance the investments in economy. Bhattacharya, Thakor ${ }^{1}$ recent studies show that the banks have a very important role in the linearization of consumership, in the sense that the banks are institutions which facilitate the linearization of consumership by the economic agents through assurance against liquidity shocks. The banking institutions can be seen as a liquidity source which ensures people against shocks, which can affect their needs of consumership ${ }^{2}$. Hence, the banks can facilitate financial crises with the help of activities realized on the financial markets, they can influence the interest rates, the uncertainty on the market as well as the asset prices.

The management activity of risk, in its large sense, represents the fundamental activity of the banks ${ }^{3}$. The banks have to control the inevitable risk of the deposits and of the portfolio of lending. Having into consideration the fact that the bankruptcy of a banking institution can have a negative effect on the financial system on the whole, it is necessary to bring under regulation and to supervise the controlling organisms which have to carefully monitor the balance of the banking operations. The specific risks for banking activities ccording to

\footnotetext{
${ }^{1}$ Bhattacharya, S., Thakor, A. (1993), Contemporary banking theory, Journal of Financial Intermediation, 3, pp.2-50

${ }^{2}$ Freixas, X., Rochet, J.C. (2008), Microeconomics of banking, 2nd ed. The MIT Press, p. 20

${ }^{3}$ Freixas, X., Rochet, J.C. (2008), Microeconomics of banking, 2nd ed. The MIT Press, p.221
} 
Heffernan ${ }^{4}$ are: the credit risk, the market risk which includes the exchanging rate and the interest rate risk, the liquidity risk, the operational risk and the systemic risk.

\section{Definition of the financial crisis}

The specialized literature has developed several theories which attempt to explain the financial crises. As each financial crisis is unique in itself, its forms, causes and consequences have been named 'conclusions', some of which are quite contradictory and therefore inconclusive. Thus, the modern economic theories reject the idea of a general theory of the economic and financial crises, as per they can be incorporated into a universal model. According to these theories, the crises cannot be anticipated so as to bring their negative effects brought to a minimum. According to Kindleberger ${ }^{5}$ crises occur spontaneously as a result of mass psychology or panic. However, history shows that they are closely related to the cyclic nature of the economic processes. Economic cycles, whether short, medium or long-termed consist of two phases - expansion and recession.

The economic literature distinguishes between three types of financial crises: currency, banking and foreign debt crises. But in practice there are no pure forms of such crises; a unique concept in economic theory is that of twin crises - the crises of currency and of the banking sector.

Thus, Kaminsky and Reinhart ${ }^{6}$ define the financial crises according to the forms they take: currency crises, banking crises and twin crises. Bordo ${ }^{7}$ defines the banking crisis as a time of financial distress, which is severe enough to result in partial or complete erosion of capital in the banking system.

The banking crisis could be defined as a difficult enough period which leads to erosion in most or all of the capital from the banking system ${ }^{8}$. The emergence of banking crises is facilitated by the liberalization process in corroboration with an inefficient legal system and a high degree of corruption ${ }^{9}$.

In another approach, Mishkin ${ }^{10}$ defined the financial crisis as a disturbance of the financial markets in which the problems of adverse selection and moral hazard become much worse. Thus, a financial crisis represents a sharp deterioration of a group of financial and economic indicators, an imbalance between the supply and demand of money, the fall of asset prices, accompanied by the failures of financial institutions such as banks.

\section{Monetarist approach for the financial crisis}

Financial crises are seen by the monetarists as a form of manifestation of the banking crises where financial stability is at risk without the intervention of the central bank. According to Friedman and Schwartz ${ }^{11}$ the failures of the banks were the result of their state of panic. When a banking institution is in trouble on the market there is a contraction of the money

\footnotetext{
${ }^{4}$ Heffernan, S.(2005), Modern Banking, John Wiley \& Sons Ltd, p. 104

${ }^{5}$ Kindleberger, C. (1978), Manias, Panics, and Crashes: A History of Financial Crises, New York: Basic Books

${ }^{6}$ Kaminsky, G., Reinhart, C.(1999), The Twin Crises: The Causes of Banking and Balance-ofPayments Problems, American Economic Review, 89, 473-500

7 Bordo, M., The Crisis of 2007 :The Same Old Story, Only the Players Have Changed, http://michael.bordo.googlepages.com/The_same_old_story.pdf

${ }^{8}$ Allen, F., Gale, D. (2001), Financial Contagion, Journal of Political Economy, 108, 1- 33, p.3

9 Demirgüc-Kunt, A., Detragiache, E. (1998), Financial Liberalization and Financial Fragility, International Monetary Fund, Working Paper 8

${ }^{10}$ Mishkin, F. (1990), Asymmetric Information and Financial Crises: A Historical Perspective, www.nber.org/papers/w3400

${ }^{11}$ Friedman, M.,Schwartz, A. (1963), A Monetary History of the United States, 1867-1960, Princeton, NJ: Princeton University Press
} 
supply, the public confidence is reduced, and this leads to the development the crisis. So banking crises occur when financial systems become illiquid or insolvent. This type of crisis relates to closures, fusions, acquisitions or assistance on the large-scale from the government. In solving this problem, the monetarists suggest an increase in the amount of money in circulation, and thus leading to the reinflation of the economy in order to counter the monetary reduction.

Thus, the inflation has been identified as a cause of financial crisis because it is seen as a purely monetary phenomenon. The inflation is related to the interest rate as well as to the money supply and a growth in inflation leads to an increase in the interest rates. Consequently, Friendman monetarists state their preference for liquidity in the same way that the monetary policies of action do on interest rates to rectify the economic activity.

Another view developed by Meltzer ${ }^{12}$ is centered on the distinction between the supply of credit and the money supply, giving an effective role to the budgetary deficit. In their view, to have a healthy growth, the monetary policy must be combined with the limitation of the budgetary deficits and with the fiscal pressure.

Another important idea is that the monetarists did not see a link between the business cycle and the crisis. The steps which the monetary authorities take to influence the demand have a delayed effect. The delay cannot be greater or smaller from one economic cycle to another, thus, because of the time lag, the anti-cyclic politics cannot lead to stability.

Finally, some monetarists proposed the establishment of a rule which would predetermine the growth of the monetary supply and would ensure monetary stability and economic growth.

\section{The hypothesis of financial fragility}

The theory of the approach to the crisis opposed to the financiers is "the hypothesis of financial fragility", a concept developed by Kindleberger and Minsky. The concept of 'fragility' seeks to clarify the problem of indebtedness during a period of revival.

Kindleberger ${ }^{13}$ believes that there are 'shocks' in the financial system which have a great impact on profitability in already existent or new sectors. The shocks which open new profit opportunities include events such as the start or the end of a war, a new technology that becomes very popular, or changes in the monetary policy. The borrower or the creditor agents move their finances to new areas of profit, financing the economic boom and supporting the increase in the supply of money. The euphoria of the investors appears and therefore the financial system starts to become fragile. The irrational behavior creates bubbles defined as excessive price increases in many areas.

Minsky ${ }^{14}$ developed Irving Fisher's approach by introducing the concept of fragility in an attempt to clarify the extent of indebtedness in an economic upswing. He wrote about the way the transition occurs from hedge-type finances to speculative finances and then to the Ponzi-type finances. He divides the crisis into five main phases, like the business cycle replacement, euphoria, climax and panic. According to Minsky, the events of a crisis begin with the 'replacement' which will increase even more the profit opportunities in at least one sector of the economy. As a result, companies invest more and more in this sector, the investment growth leading the economy to the 'euphoric' stage. At this stage, the bank will extend the credit expecting higher profits in the sector. The increased investment will lead to a price boost which will create more opportunities for profit, which is called 'climax'.

\footnotetext{
${ }^{12}$ Meltzer, A. H. (1982), Rational Expectations, Risk, Uncertainty, and Market Respones, Lexinton Books

${ }^{13}$ Kindleberger, C. (1978), Manias, Panics, and Crashes: A History of Financial Crises, New York: Basic Books

${ }^{14}$ Minsky, H. (1972), An Evaluation of Recent Monetary Policy, Nebraska Journal of Economics and Business, Vol. 11, No. 4, pp. 37-56
} 
Artificial price increases take place here, the investors earning a maximum profit. There is a small price variation at this level because of the government policy change or because of an increase in interest rates which will lead to 'panic'. At this stage, the economic activity slows down, and bankruptcies and increased unemployment comes to the surface.

\section{The risk and the uncertainty}

The risk of uncertainty and the risk compared to the uncertainty are two antithetical epistemologies that form the economic theory of the 20th century. The inclusion of risk and uncertainty in the economic theory has raised at least two problems: (1) the definition and delimitation of the concepts of risk and uncertainty, (2) the assessing of risk and uncertainty and the way in which these concepts affect economic decisions.

In explaining the financial crisis, Knight ${ }^{15}$ first suggested the economic uncertainty, and not the risk. It is important to distinguish between two concepts. Quantify the risk usually reachable but unquantifiable uncertainties. Currently, we can appreciate that risk management is an art, developing a genuine culture of risk. The study of 'Economic Uncertainty' can be divided into two main schools (1) mainstream (the Keynesian school) and (2) the Austrian school. In general, the two schools define uncertainty in the same way, so the uncertainty can be measured by the evaluation of probabilities, of associated risks, as well as of the benefits, every possible result. But the Austrian school of economics sustains that uncertainty is applicable to events, implications, such as wars, major changes in political regimes, financial crises, etc.

According to the Austrian school of economics, the market uncertainty is the main source of stability and innovation. In terms of opportunities for profit, the uncertainty which is in continual change represents, according to Knight, a primary source of competitive markets. If all the probabilities have been known and the risk has been diversified, there would be no additional profit and the entrepreneurs would no longer be motivated to do business. The profits are made from innovation and from the search for opportunities.

In 1944 - John von Neumann and Oskar Morgensten ${ }^{16}$ realised for the first time the formalized incorporation of risk and of uncertainty in the economic theory (in his "Theory of games and economic behavior"). They have developed an objective approach to adopting decisions under conditions of risk, formulating the hypotheses of anticipated utility (expected profit) using the statistic probabilities. Another step is made by Friedman and Markowitz ${ }^{17}$ who analysed the concept of adversity in connection with risk and in contradiction with the appetite for risk, as well as the relative properties of the anticipated utility.

\section{The problem of information asymmetry and the financial crisis}

A number of researches have been done on the issue of information asymmetry and its relationship with the financial crisis. The information asymmetry means the lack of information between entities which exist on the financial market. All the contracts and transactions are based on information ${ }^{18}$. In a transaction not all participants are fully informed, or have the same information, and either party may possess information which is not available to others. The most important entities are the debtors and the creditors and the problem of information asymmetry could exist in the financial contracts between them. The

\footnotetext{
${ }^{15}$ Knight, F.(1921), Risk, uncertainty and profit, Boston: Houghton Mifflin, http://www.econlib.org/library/Knight/knRUP.html

16 Morgenstern, O., Neumann, J. (1944), Theory of Games and Economic Behavior, Princeton Univerity Press

17 Markowitz, H.M. (2005),Market Efficiency: A Theoretical Distinction and So What?, Financial Analysts Journal, 61 (5): 17-30

${ }^{18}$ Casu, B., Girardone, C., Molyneux, P. (2006), Introduction to Banking, Financial Times Press, p.9
} 
borrower has better information than the creditor concerning the productivity of the project or the risks associated with this project, while the creditor lacks this information. In this case, the creditor increases the interest rate, being able to exclude the high-quality borrowers and he may also choose to better rationalize loans rather than increase interest rates in order to avoid adverse selection ${ }^{19}$.

The asymmetric information creates problems in the financial structure in two ways - before the closing of the so-called transaction and the adverse selection and also after the closing of the transaction called the moral hazard.

The banks may hold private information that has not yet reached the financial market. For example, if a customer asks for a financing, the bank has the possibility to evaluate him because it manages his accounts and can also obtain important information regarding turnover, profitability and indebtedness. Therefore, the bank prevents the concealment of information before signing the agreement and thus reduces the asymmetry of information that would lead to adverse selection.

The moral hazard is the final result of asymmetric information that results when the transaction takes place. This occurs because of the borrowers who invest in projects with high risk, the creditors having to support most of the loss in case the project fails. Such asymmetry as shown later leads to the idea of morality, meaning that intermediaries can reduce monitoring costs and may provide statistical and accounting methods by using specialized services. A careful monitoring of agreements is thus provided and the risk of bankruptcy is also decreased. The banks have a well defined role in lowering information asymmetry as they maintain long term relationships with their customers, through the very nature of the performed functions.

Mishkin $^{20}$ identified five reasons for the production of the financial crisis: (1) it raises interest rates (2) it decreases property market (3) the increase of uncertainty (4) the bank is panicking and (5) unexpected drop in the aggregate price level. He said that these five reasons for financial crisis are the result of the problem of information asymmetry. The increase in uncertainty, or higher interest rates and the stock market crash increased the austerity level of adverse selection on the credit market, while the decrease of the net value resulting from a decrease in property market has increased morale, which will eventually lead to a crisis. The theory of financial crisis explains the causes but does not explain how it develops and what those signs of financial crisis are. Moreover, the problem of information asymmetry is not the only cause of the financial crisis. The role of government or government policy failure is not taken into consideration in this theory.

\section{Conclusions}

The opportunities offered nowadays by the volume and pace of change on the financial markets have proven to be both a source of profit and one of loss. The development of the financial innovations and the hazardous speculations, the lending expansion and the increase in asset prices without an economic base are inevitable, as long as the investors wish to get the best profits. The studies ${ }^{21}$ have shown that, more often than not, the banking crises have been preceded by an excessive exposure of the banks on the capital and property markets. In these conditions, the occurrence of the financial crises doesn't represent anything new.

There are many causes of the banking crises, but they are generally grouped into three main categories:

\footnotetext{
${ }^{19}$ Stiglitz, J.,Weiss, A.(1981), Credit Rationing in Markets with Imperfect Information, The American Economic Review, Vol. 71, No. 3, pp. 393-410

${ }^{20}$ Mishkin, F. (2001), Financial Policies and the Prevention of Financial Crises in Emerging Market Countries, NBER Working Paper w8087

${ }^{21}$ Kaminsky, G., Reinhart, C.(1999), The Twin Crises: The Causes of Banking and Balance-ofPayments Problems, American Economic Review, 89, 473-500
} 
- the unfavorable development of the macroeconomic framework;

- the imprudent behavior and the poor corporate governance of the banks;

- the authorities' involvement in the decisions of lending service offered by the banks, namely, the political interference in an activity which must run only on economic criteria.

\section{Bibliografie}

1. Allen, F., Babus, A., Carletti, E. (2009), Financial Crises: Theory and Evidence, http://fic. wharton.upenn.edu/fic/papers/09/0915.pdf

2. Allen, F., Carletti, E. (2006), Credit Risk Transfer and Contagion," Journal of Monetary Economics, $53,89-111$

3. Allen, F., Gale, D. (2007), An introduction to financial crises, http://fic.wharton.upenn.edu/fic/papers/07/p0720.html

4. Allen, F., Gale, D. (2001), Financial Contagion, Journal of Political Economy, 108, 1- 33

5. Bordo, M., The Crisis of 2007 :The Same Old Story, Only the Players Have Changed, http://michael.bordo.googlepages.com/The_same_old_story.pdf

6. Bhattacharya, S., Thakor, A. (1993), Contemporary banking theory, Journal of Financial Intermediation, 3

7. Casu, B., Girardone, C., Molyneux, P. (2006), Introduction to Banking, Financial Times Press

8. Dell'Ariccia, G., Detragiache, E., Rajan, R(2008), The real effect of banking crises, Journal of Financial Intermediation - vol. 17, No. 1, p. 1-144

9. Demirgüc-Kunt, A., Detragiache, E. (1998), Financial Liberalization and Financial Fragility, International Monetary Fund, Working Paper 83

10. Freixas, X., Rochet, J.C. (2008), Microeconomics of banking, 2nd ed. The MIT Press

11. Heffernan, S.(2005), Modern Banking, John Wiley \& Sons Ltd

12.Kaminsky, G., Reinhart, C.(1999), The Twin Crises: The Causes of Banking and Balance-ofPayments Problems, American Economic Review, 89, 473-500

13.Kindleberger, C. (1978), Manias, Panics, and Crashes: A History of Financial Crises, New York: Basic Books

14. Knight, F.(1921), Risk, uncertainty and profit, Boston: Houghton Mifflin, http://www.econlib.org/library/Knight/knRUP.html

15. Friedman, M.,Schwartz, A. (1963), A Monetary History of the United States, 1867-1960, Princeton, NJ: Princeton University Press

16. Markowitz, H.M. (2005),Market Efficiency: A Theoretical Distinction and So What?, Financial Analysts Journal, 61 (5): 17-30

17. Meltzer, A. H. (1982), Rational Expectations, Risk, Uncertainty, and Market Respones, Lexinton Books

18.Minsky, H. (1972), An Evaluation of Recent Monetary Policy, Nebraska Journal of Economics and Business, Vol. 11, No. 4, pp. 37-56

19. Minsky, H.(2008), Stabilizing An Unstable Economy, McGraw Hill Companies

20. Mishkin, F. (1990), Asymmetric Information and Financial Crises: A Historical Perspective, www.nber.org/papers/w3400.

21. Mishkin, F. (2001), Financial Policies and the Prevention of Financial Crises in Emerging Market Countries, NBER Working Paper w8087

22. Morgenstern, O., Neumann, J. (1944), Theory of Games and Economic Behavior, Princeton Univerity Press

23. Stiglitz, J.,Weiss, A.(1981), Credit Rationing in Markets with Imperfect Information, The American Economic Review, Vol. 71, No. 3, pp. 393-410. 